\title{
Vertical Greenery Systems as sustainable solutions for building retrofitting: a case study
}

\author{
A. Martínez-Rocamora ${ }^{1}$, R.M. Pulselli ${ }^{2}$, J. Solís-Guzmán ${ }^{1}$, \\ M. Marrero ${ }^{1} \&$ S. Bastianoni ${ }^{2}$ \\ ${ }^{I}$ Department of Building Construction II, School of Building Engineering, \\ University of Seville, Spain \\ ${ }^{2}$ Ecodynamics Group, Department of Physical, Earth and \\ Environmental Sciences, University of Siena, Italy
}

\begin{abstract}
In this paper, an environmental impact assessment has been developed for evaluating advantages and disadvantages of installing a Vertical Greenery System (hereafter VGS) on two south-oriented facades of a building, together with movable wooden slats on its windows. Initial investment has been compared to annual maintenance costs and energy savings in terms of equivalent solar energy, based on the eMergy method. An existing building in Siena (Italy) was taken as a case study. Thermal performances were simulated based on reliable parameters. These were hypothesized for modelling the envelope and windows as well the effects of the VGS and slats on indoor climate conditions.

Results showed that installing the VGS and wooden slats over the south-west and south-east facades (around $800 \mathrm{~m}^{2}$ ) would decrease the cooling energy demand during warm months of around $50 \%$ and highlighted the environmental profitability of the proposed solution for a $130,000 \mathrm{~m}^{3}$ building. Compared to previously published results $\left(98 \mathrm{~m}^{2}\right.$ VGS of a $1000 \mathrm{~m}^{3}$ detached house) which report a quota of $15 \%$ cooling energy saving, this model demonstrates that potential benefits of VGS can significantly increase due to the scale-factor (i.e. dimension of facades and building volumes) and the combination with wooden slats.
\end{abstract}

Keywords: eMergy evaluation, cooling energy saving, living wall, sustainable development solutions. 


\section{Introduction}

Vertical Greenery Systems (VGS) are vegetated structures conceived to be installed on building facades. In this paper, we consider a type of VGS based on a hydroponic technology for nurturing plants, namely Living Wall. In this case, plants are rooted in felt layers fixed on PVC panels and anchored on the building facade by an aluminium frame.

The effects of VGS in terms of cooling energy saving have been widely documented in literature [1-7]. In particular, Pulselli et al. [2] simulated the thermal effect of a VGS installed on a $98 \mathrm{~m}^{2}$ south-oriented facade of a $1000 \mathrm{~m}^{3}$ detached house and, based on measurements on prototypes [1], they figured out a cooling energy saving in warm months of around $15 \%$ of total cooling energy (this is 624 out of a total cooling energy demand of $4100 \mathrm{kWh} \mathrm{yr}^{-1}$ ). This value refers to a scenario with the external envelope made of massive walls. Due to unclear fluctuations detected on the prototypes [1], it was argued that thermal effects during cold months cannot be easily simulated because the negative shadow effect is most likely compensated by the additional insulation due to the air-cavity and the protection from wind due to the vegetated cover. The effect in winter was therefore considered negligible [2].

Moreover, Pulselli et al. [2] showed results from an environmental accounting method, namely EMergy Evaluation, in order to calculate the environmental resource appropriation for the manufacturing (including plants production, transport and panels assembling in the greenhouse) and maintenance (based on the removal and replacement of death plants and deteriorated structures) of the VGS, as well as for its sustenance (watering and nurturing automatic system). This allows for comparing "environmental costs" (i.e. the eMergy needed for the manufacturing, maintenance and sustenance processes), expressed in equivalent solar energy (the unit of eMergy: solar eMergy Joule - seJ), with benefits (i.e. the cooling energy saving, in eMergy terms). The Cost-to-Benefit ratio demonstrated that benefits can compensate the initial eMergy investment (i.e. costs) within a 25year lifespan. This result is conditioned to the use of local resources (e.g. plants produced locally instead of imported from the Netherlands) to avoid transportation and to the implementation of an integrated rainwater harvesting system to avoid the use of tap water.

Other environmental issues of VGS have been documented: Ottelé et al. [8] proved that leaf surfaces work as a sink for health-damaging particles from the atmosphere, thus improving air quality. Wong et al. [9] demonstrated that VGS have one of the highest sound absorption coefficient as compared with other conventional building materials. Currently, a new European partnership is developing the UGreenS Leonardo research project on this field, which is mainly focused on green roofs and living walls [10]. Also a review of recent studies focused on VGS can be found in Hunter et al. [11].

In this paper, an office building located in Italy, the headquarter of the Chamber of Commerce of Siena (hereafter CCS building), is taken as a case study in order to analyze the effects of a VGS installed on two facades (south-east and southwest) of a $130,000 \mathrm{~m}^{3}$ building, combined with wooden slats on windows. The 
CCS building was built during the 50s (Fig. 1) and has been severely criticized for breaking the landscape harmony of the city center and also for its uncomfortable indoor climate during warm months, due to the massive wall envelope and windows. Modifying its envelope by integrating a VGS on two facades is a reliable option for its retrofitting and also for improving its energy efficiency and allowing for cooling energy saving. An extruded 3D model with details of the structural elements is shown in fig. 1.

The general objective of this study is to assess potential effects of a VGS installed on a whole $812 \mathrm{~m}^{2}$ south-oriented surface of a huge size building, also combined with wooden slats, in order to estimate how the dimensional scale of both the building and the facade can affect results. Specific aims are:

- $\quad$ to investigate the energy performance of VGS based on a simulation model in order to hypothesize the potential effects of a VGS installed on two south-oriented facades together with wooden slats on windows;

- $\quad$ to estimate the environmental performance based on a Cost-to-Benefit balance by comparing the comprehensive environmental resource use for VGS manufacturing and sustenance (costs) with the energy saving due to the augmented thermal performance of the envelope (benefits).

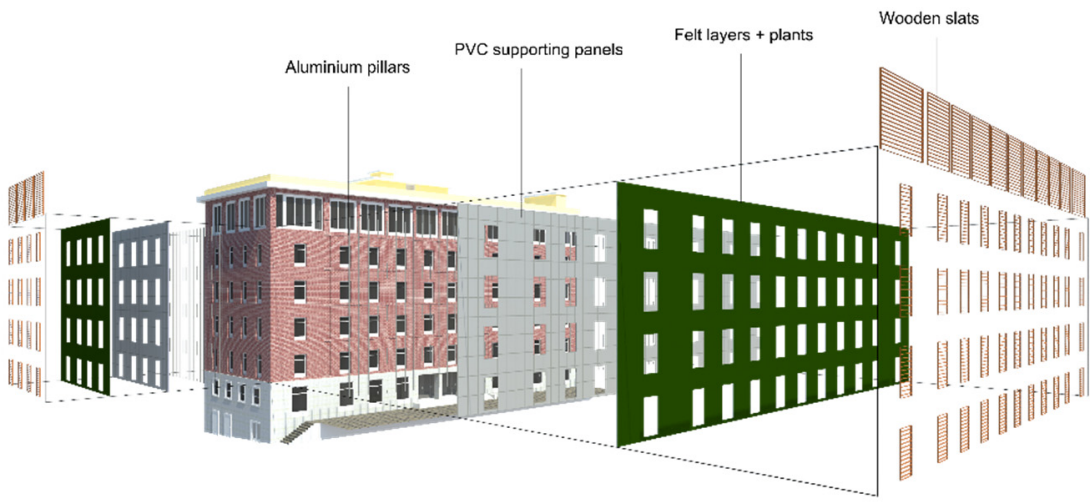

Figure 1: Extruded 3D model of the installation of VGS and wooden slats on the facade of the CCS building.

\section{Materials and methods}

For the energy simulation, the CE3X software, has been used [12] in order to estimate the energy demand in both the scenarios: $a$ ) the current massive wall envelope, and $b$ ) added VGS on two south-oriented facades together with wooden slats on windows.

In the first scenario $(a)$, climate has been set to humid subtropical (Cfa according to the Köppen-Geiger climate classification), characterized by hot, humid summers and generally mild, rainy winters. The coldest month's mean 
temperature usually stays between -3 and $18^{\circ} \mathrm{C}$, and in the warmest month it rises above $22^{\circ} \mathrm{C}$. Each component has been simulated using the following thermal transmittance values: massive brickwork envelope $\left(1.51 \mathrm{~W} / \mathrm{m}^{2} \mathrm{~K}\right.$ - facades southwest, south-east and north-east), massive brickwork and concrete blocks envelope $\left(1.45 \mathrm{~W} / \mathrm{m}^{2} \mathrm{~K}\right.$ - facade north-west), wall in contact with the ground $\left(1.03 \mathrm{~W} / \mathrm{m}^{2} \mathrm{~K}\right)$, basement floor $\left(0.41 \mathrm{~W} / \mathrm{m}^{2} \mathrm{~K}\right)$, roof $\left(2.50 \mathrm{~W} / \mathrm{m}^{2} \mathrm{~K}\right)$ and windows $\left(5.70 \mathrm{~W} / \mathrm{m}^{2} \mathrm{~K}\right)$.

In the second scenario (b), the VGS installed on both the south-west and southeast facades was simulated by configuring each layer within CE3X, improving their thermal transmittance to the interval $0.81-0.95 \mathrm{~W} / \mathrm{m}^{2} \mathrm{~K}$. Using movable wooden slats in both facades' windows changed their shadow factor to 0.3 in summer (assumed disposed in horizontal position with a $60^{\circ}$ angle) and 0.8 in winter (assumed open to not avoid heat gain).

The VGS is composed of an aluminium frame anchored to the facade, which forms a $5 \mathrm{~cm}$ air-cavity, then a PVC layer ( $1 \mathrm{~cm}$ thick), and four overlaid felt layers constantly wet where the plants are embedded. It also must have HDPE pipes for nurturing plants with water and fertilizers [2]. This configuration has been simulated as a ventilated facade, since the $5 \mathrm{~cm}$ air-cavity is considered to be open.

The CE3X allows for configuring the building by spaces and orientations. Spatial parameters, such as area and external-walls composition (layers, orientation, and windows) - are specified for each space. Spaces in each floor have been classified as shown in fig. 2: one for rooms located in a corner (red), another

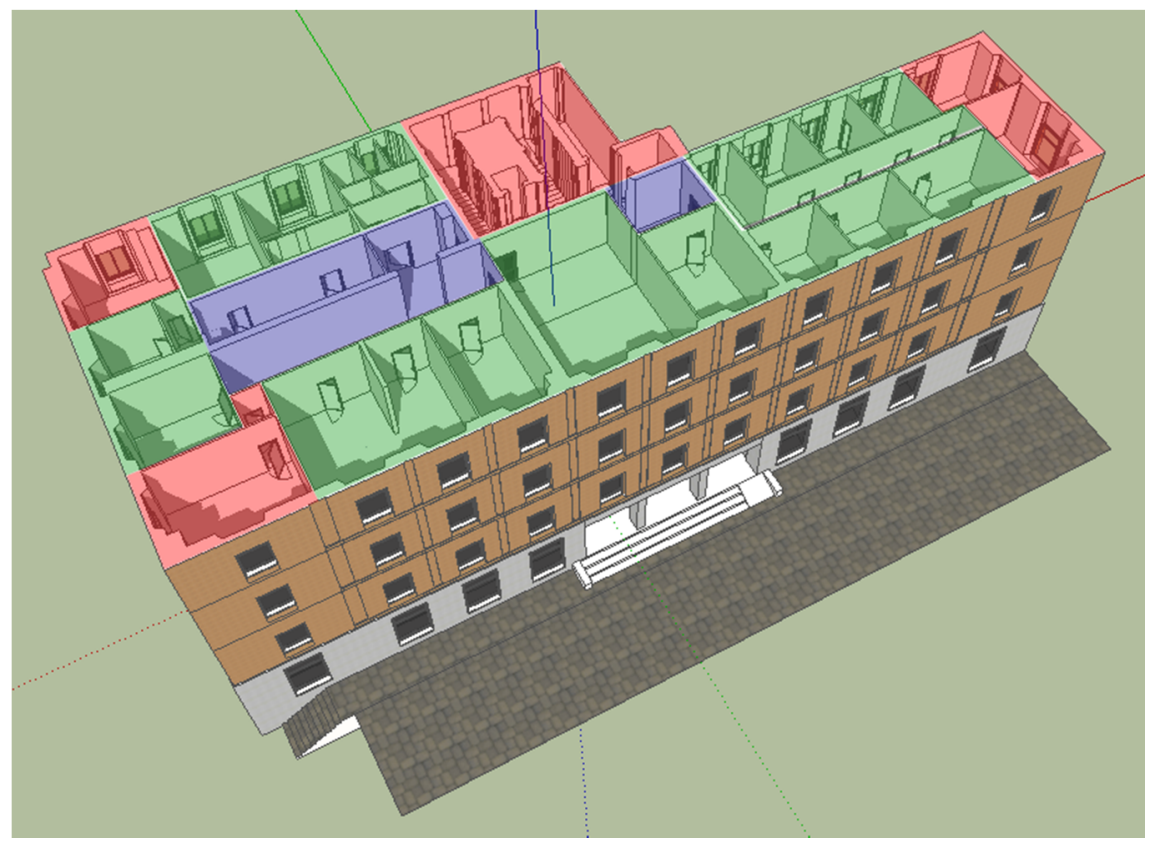

Figure 2: Classification of spaces based in the CCS building (third floor). 
for rooms with the same orientation (green), and finally internal spaces (blue). This simplified model allows for simulating the thermal behavior of these three spatial categories and estimating their energy demand.

For the environmental profiling of the VGS, an accounting method, namely eMergy evaluation (EME), has been implemented. The eMergy concept was defined by Odum [13] as the solar energy (Unit: solar eMergy Joules - seJ) needed directly or indirectly to obtain a given product. The general principle is that quantities of energy and mass can be converted into eMergy using specific eMergy values, conversion factors expressed in $\mathrm{se} J / \mathrm{J}$ or $\mathrm{seJ} / \mathrm{kg}$. EME has been applied for the assessment of construction processes and building materials [14-16]. Based on results from EME, the Cost to Benefit Ratio (CBR) can be assessed as follows [2]:

$$
C B R_{n}=\frac{I+S_{n} \times n}{E_{n} \times n} \lessgtr 1
$$

where $I$ is the initial eMergy investment for VGS manufacturing (it does not include renewables and human work), $S_{n}$ is the yearly eMergy inflow for VGS sustenance, $E_{n}$ is the yearly energy saving in eMergy terms, and $n$ is the number of years to achieve a comprehensive balance. The number of years needed to have costs be compensated by benefits ( $\mathrm{CBR}=1$ indicates a balanced condition), is a crucial information to determine VGS sustainability.

\section{Results and discussion}

Specific eMergy values of VGS (Living Wall type) were provided by Pulselli et al. [2]. Considering a whole 25yrs lifespan for a VGS installation, the total eMergy investment for VGS manufacturing and sustenance is $7.25 \mathrm{E}+12 \mathrm{seJ} \mathrm{m} \mathrm{Jr}^{-1}$


$47.6 \%$ of the total. Given a facade area of $812 \mathrm{~m}^{2}$, the total investment for the VGS installation on the CCS building and its operation in 25 years would be $1.47 \mathrm{E}+17$ seJ. Considering that renewable resources (4.6\%) and human work $(29.2 \%)$ do not represent direct environmental impacts, the total eMergy investment for VGS in eqn (1) would be $9.74 \mathrm{E}+16$ seJ. Moreover, solutions for decreasing impacts, such as the use of rainwater instead of tap water $(25.3 \%)$ and the implementation of a short distance supply chain (plants produced locally instead of imported) in order to avoid transportation (3.5\%), would bring this value to $5.45 \mathrm{E}+16 \mathrm{seJ}$.

The eMergy use for the installation and maintenance of wooden slats in every window of the south-west and south-east facades has also been calculated as part of the proposed intervention (Table 1). Unit EMergy Values in column \#5 have been retrieved from the references in column \#6. The eMergy investment for


of $4.60 \mathrm{E}+14 \mathrm{seJ} \mathrm{yr}^{-1}$, resulting in a total eMergy use of $8.43 \mathrm{E}+14 \mathrm{seJ} \mathrm{yr}^{-1}$. In eqn (1), the eMergy investment, without human work, would be $1.95 \mathrm{E}+16 \mathrm{seJ}$ in a 25-year lifetime. 
Table 1: EMergy Evaluation of manufacture and maintenance of wooden slats.

\begin{tabular}{|c|c|c|c|c|c|c|c|c|}
\hline & DETAIL & $\begin{array}{c}\text { Raw } \\
\text { data } \\
\left(477 \mathrm{~m}^{2}\right. \\
\text { windows } \\
)\end{array}$ & $\begin{array}{c}\text { Uni } \\
t\end{array}$ & $\begin{array}{c}\text { Lifetim } \\
\text { e } \\
\text { (yrs) }\end{array}$ & $\begin{array}{l}\text { QUANTITY } \\
\text { (unit } \mathbf{y r}^{-1} \text { ) }\end{array}$ & $\begin{array}{c}\text { UEV } \\
\left(\text { seJ unit }^{-1}\right)\end{array}$ & $\begin{array}{c}\text { RE } \\
\text { F }\end{array}$ & $\begin{array}{c}\text { EMERGY } \\
\left(\mathrm{seJ} \mathrm{yr}^{-1}\right)\end{array}$ \\
\hline \multicolumn{8}{|c|}{ WOODEN SLATS INSTALLATION } & $3.83 E+14$ \\
\hline \multirow[t]{4}{*}{ Horizontal slats } & wood & 3730.14 & $\mathrm{~kg}$ & 25 & 149.21 & $3.97 \mathrm{E}+11$ & {$[18]$} & $5.92 \mathrm{E}+13$ \\
\hline & aluminium & 286.20 & $\mathrm{~kg}$ & 25 & 11.45 & $1.27 \mathrm{E}+13$ & [19] & $1.45 \mathrm{E}+14$ \\
\hline & varnish & 243.10 & $\mathrm{~kg}$ & 25 & 9.72 & $1.49 \mathrm{E}+13$ & {$[16]$} & $1.45 \mathrm{E}+14$ \\
\hline & $\begin{array}{c}\text { human } \\
\text { work }\end{array}$ & 192.00 & $\mathrm{~h}$ & 25 & 7.68 & $4.34 \mathrm{E}+12$ & {$[20]$} & $3.33 \mathrm{E}+13$ \\
\hline \multicolumn{8}{|c|}{ WOODEN SLATS MAINTENANCE } & $4.60 \mathrm{E}+14$ \\
\hline \multirow[t]{2}{*}{ Varnishing } & varnish & 243.10 & $\mathrm{~kg}$ & 10 & 24.31 & $1.49 \mathrm{E}+13$ & {$[16]$} & $3.62 \mathrm{E}+14$ \\
\hline & $\begin{array}{c}\text { human } \\
\text { work }\end{array}$ & 64.00 & $\mathrm{~h}$ & 10 & 6.40 & $4.34 \mathrm{E}+12$ & {$[20]$} & $2.78 \mathrm{E}+13$ \\
\hline \multirow[t]{2}{*}{ Cleaning } & water & 220.00 & $\mathrm{~kg}$ & 1 & 220.00 & $1.84 \mathrm{E}+09$ & {$[21]$} & $4.05 \mathrm{E}+11$ \\
\hline & $\begin{array}{c}\text { human } \\
\text { work }\end{array}$ & 16.00 & $\mathrm{~h}$ & 1 & 16.00 & $4.34 \mathrm{E}+12$ & {$[20]$} & $6.94 \mathrm{E}+13$ \\
\hline \multicolumn{8}{|c|}{ TOTAL EMERGY } & $8.43 E+14$ \\
\hline
\end{tabular}

An energy simulation has been made in order to calculate potential energy savings. The CCS building theoretically demands for around $132-145 \mathrm{kWh} \mathrm{m}^{-2}$ $\mathrm{yr}^{-1}$ for heating (i.e. $608,900-669,400 \mathrm{kWh} \mathrm{yr}^{-1}$ for the whole $4614 \mathrm{~m}^{2}$ building) and around 21-28 $\mathrm{kWh} \mathrm{m}^{-2} \mathrm{yr}^{-1}$ for cooling (i.e. 96,900-129,200 $\mathrm{kWh} \mathrm{yr}^{-1}$ ). As it was mentioned in the introduction, effects of VGS and wooden slats in winter have been considered negligible.

By taking cautious interval values for the thermal transmittance of the facade with the VGS added $\left(0.81-0.95 \mathrm{~W} / \mathrm{m}^{2} \mathrm{~K}\right)$ and the use profile (medium to high intensity $-12 \mathrm{~h}$ ), results showed that the combined use of VGS and wooden slats over the south-west and south-east facades would decrease the cooling energy demand in summer to $9.73-14.75 \mathrm{kWh} \mathrm{m}^{-2} \mathrm{yr}^{-1}\left(44,900-68,000 \mathrm{kWh} \mathrm{yr}^{-1}\right)$. The estimated energy saving in the CCS building is therefore within the interval $52,000-61,200 \mathrm{kWh} \mathrm{yr}^{-1}$. The cooling energy saving in the CCS building ranges from $54 \%$ to $47 \%$, respectively, of the total energy demand for cooling.

In eMergy terms, the cooling energy saving corresponds to $2.79 \mathrm{E}+16$ $3.28 \mathrm{E}+16 \mathrm{seJ} \mathrm{yr}^{-1}(\mathrm{UEV}=1.49 \mathrm{E}+05 \mathrm{seJ} / \mathrm{J}[22])$. In eqn (1) this value is the $\mathrm{E}_{\mathrm{n}}$ with $\mathrm{n}=1$. We also calculated the investment I for the manufacturing, maintenance and sustenance of both the VGS and the wooden slats in 25 years as equal to $1.17 \mathrm{E}+$ $17 \mathrm{seJ}$ (this value does not include renewables and human work). We can therefore estimate that the Cost to Benefit ratio is balanced (i.e. $\mathrm{CBR}=1$ ) within a time interval of 3.6-4.2 yrs, that is 43-50 months. If we consider the mitigating measures, such as an integrated water harvesting system and a limited transportation by using local plants, this decreases to $2.3-2.7$ years. 


\section{Conclusions}

The environmental performance of Vertical Greenery Systems (VGS) installed on building facades was investigated with reference to an Italian case study (the VGS was hypothesized installed on two south-oriented facades of a $130,000 \mathrm{~m}^{3}$ building). An environmental accounting method, namely eMergy evaluation, was implemented for comparing environmental costs (resource use for VGS manufacturing and sustenance and wooden slats) with benefits (cooling energy saving, in eMergy terms).

The cooling energy demand was estimated through a simulation model that theoretically represents the building envelope, as well as the VGS and the wooden slats on windows. This was developed to hypothesize potential effects based on climate conditions, shapes and energy performance of the assembled elements. Outcomes showed that the proposed solution of VGS, together with wooden slats, would reduce the energy demand for cooling by $47-54 \%$. Compared to previously published results which report a quota of $15 \%$ cooling energy saving by a $98 \mathrm{~m}^{2}$ VGS installed on a $1000 \mathrm{~m}^{3}$ detached house (without wooden slats) [2], this model demonstrates that potential benefits of VGS can significantly increase with the scale-factor (i.e. dimension of facades and building volumes) and in combination with wooden slats.

The Cost-to-Benefit ratio demonstrated that benefits, in eMergy terms, can compensate the initial eMergy investment within 3.6-4.2 years. It is to highlight anyway that these results are based on theoretical models and would need a confirmation through the monitoring of real installation and pilot projects. Nevertheless, based on this study, VGS look to be promising solutions for building retrofitting that, in given conditions, can increase energy efficiency.

Besides environmental issue, the current high market prizes condition VGS feasibility from an economic viewpoint. Nevertheless, the environmental results make VGS a desirable solution for building retrofitting, in certain conditions (e.g. Mediterranean climate contest, south oriented facades, massive wall envelope, huge scale buildings and facades). This suggests that the energy regulation and subsidy policies for energy efficiency could be successfully extended to VGS in the next future.

\section{References}

[1] Mazzali, U., Peron, F., Romagnoni, P., Pulselli, R.M. \& Bastianoni, S., Experimental investigation on the energy performance of living walls in temperate climate. Building and Environment, 64, pp. 57-66, 2013.

[2] Pulselli, R.M., Pulselli, F.M., Mazzali, U., Peron, F. \& Bastianoni, S., Emergy based evaluation of environmental performances of Living Wall and Grass Wall systems. Energy and Buildings, 73, pp. 200-211, 2014.

[3] Kontoleon, K.J. \& Eumorfopoulou, E.A., The effect of the orientation and proportion of a plant-covered wall layer on the thermal performance of a building zone. Building and Environment, 45, pp. 1287-1303, 2010. 
[4] Wong, N. H., Kwang Tan, A.Y., Chen, Y., Sekar, K., Tan, P.Y., Chan, D., Chiang, K. \& Wong, N.C., Thermal evaluation of vertical greenery systems for building walls. Building and Environment, 45(3), pp. 663-672, 2010.

[5] Wong, N.H., Kwang Tan, A.Y., Tan, P.Y. \& Wong, N.C., Energy simulation of vertical greenery systems. Energy and Buildings, 41, pp. 1401-1408, 2009.

[6] Pérez, G., Rincón, L., Vila, A., González, J.M. \& Cabeza, L. F., Behaviour of green facades in Mediterranean Continental climate. Energy Conversion and Management, 52, pp. 1861-1867, 2011.

[7] Tilley, D., Price, J., Matt, S. \& Marrow, B., Vegetated Walls: Thermal and Growth Properties of Structured Green Facades. Final Report to Green Roofs for Healthy Cities-Green Walls Group. Ecosystem Engineering Design Lab, Environmental Science and Technology Department College of Agriculture and Natural Resources, Maryland, Agricultural Experiment Station, University of Maryland, College Park, p. 163, 2012.

[8] Ottelé, M., van Bohemen, H.D. \& Fraaij, A., Quantifying the deposition of particulate matter on climber vegetation on living walls. Ecological Engineering, 36, pp. 154-162, 2010.

[9] Wong, N.H., Kwang Tan, A.Y., Yok Tan, P., Chiang, K. \& Wong, N.C., Acoustics evaluation of vertical greenery systems for building walls. Building and Environment, 45, pp. 411-420, 2010.

[10] UGreens. UGreenS research project website, 2014. http://www.ugreens.eu/ index.php (accessed 03.04.14).

[11] Hunter, A.M., Williams, N.S.G., Rayner, J.P., Aye, L., Hes, D. \& Livesley, S.J., Quantifying the thermal performance of green facades: A critical review. Ecological Engineering, 63, pp. 102-113, 2014.

[12] Ministry of Industry, Energy and Tourism of Spain. CE3X, simplified procedure for energy certification of existent buildings, 2014. http://www.minetur.gob.es/energia/desarrollo/eficienciaenergetica/certific acionenergetica/documentosreconocidos/paginas/procedimientossimplifica dosparaedificiosexistentes.aspx (accessed 03.04.14).

[13] Odum, H.T., Environmental accounting: Emergy and environmental decision making. Chichester Wiley, New York, NJ, 1996.

[14] Pulselli, R.M., Simoncini, E., Pulselli, F.M. \& Bastianoni, S., Emergy analysis of building manufacturing, maintenance and use: Em-building indices to evaluate housing sustainability. Energy and Buildings, 39, pp. 620-628, 2007.

[15] Meillaud, F., Gay, J.B. \& Brown, M.T., Evaluation of a building using the emergy method. Solar Energy, 79, pp. 204-212, 2005.

[16] Brown, M.T. \& Buranakarn, V., Emergy indices and ratios for sustainable material cycles and recycle options. Resources, Conservation and Recycling, 38, pp. 1-22, 2003.

[17] Campbell, D.E., A revised solar transformity for tidal energy received by the earth and dissipated globally: implications for Emergy Analysis. Proceedings $1^{\text {st }}$ Biennial Emergy Analysis Research Conference, eds. M.T. Brown, S.L. Brandt-Williams, D.R. Tilley \& S. Ulgiati. Center for 
Environmental Policy, Department of Environmental Engineering Sciences, University of Florida: Gainesville, FL, pp. 255-264, 2000.

[18] Castellini, C., Bastianoni, S., Granai, C., Dal Bosco, A. \& Brunetti, M., Sustainability of poultry production using the emergy approach: Comparison of conventional and organic rearing systems. Agriculture, Ecosystems and Environment, 114, pp. 343-350, 2006.

[19] Odum, H.T., Material calculation, energy hierarchy, and building construction. Construction Ecology, Nature as the Basis of Green Buildings, eds. C.J. Kibert, J. Sendzimir, G.B. Guy, SPON Press/Taylor and Francis: London and New York, pp. 37-71, 2002.

[20] Morandi, F., A new insight to emergy by means of set theory: Theoretical and applicative aspects (Ph.D. Dissertation). University of Siena, Italy, 2012.

[21] Pulselli, F.M., Patrizi, N. \& Focardi, S., Calculation of the unit emergy value of water in an Italian watershed. Ecological Modelling, 222, pp. 2929-2938, 2011.

[22] Caruso, C., Catenacci, G., Marchettini, N., Principi, I. \& Tiezzi, E., Emergy based analysis of Italian electricity system. Journal of Thermal Analysis and Calorimetry, 66, pp. 265-272, 2001. 